arranged for the peripheral speed of his 'windmill' to be several times as great as the highest horizontal speed of the entire craft, and since this peripheral speed remained nearly constant, the craft could always count on adequate lift, however slowly the machine as a whole might be flying. In fact experiment soon showed that against a modest wind of twenty miles an hour or so, the autogiro could keep station in descent over a definite spot on the ground.

The autogiro could, however, not compete with a helicopter in vertical 'take-off', and it was to this point that Señor Cierva devoted the later years of his life. He devised a mechanism whereby the pitch angle of the rotating blades of the windmill could be changed, and he used this mechanism to change, from a zero pitch angle to a large one, the angle of attack of the rotating blades at the moment of starting flight. This caused the craft literally to jump into the air -as much as 30 feet-and then to climb on a gentle path free from ground obstructions. In this way, the inventor considered that he had added to his autogiro the main advantage claimed for the helicopter of being able to rise from a very small field.

At each stage in the development of his ideas, Señor Cierva gave an account of his work to the Royal Aeronautical Society, of which he was a fellow. From that Society he received its Silver
Medal and later the Wakefield and Guggenheim Gold Medals. In his lifetime he always expressed himself warmly on the recognition he received from the Royal Aeronautical Society, as he did on the encouragement given to him by the Air Ministry and the Aeronautical Research Committee, from his earliest flying demonstration to an astonished assemblage at Farnborough until the day of his death.

We regret to announce the following deaths:

Dr. L. Gustave Binger, correspondant for the Section of Geography and Navigation of the Paris Academy of Sciences.

Prof. William Campbell, Howe professor of metallurgy in Columbia University, an authority on physical metallurgy, on December 16, aged sixty years.

Prof. Augustus H. Gill, emeritus professor of chemistry in the Massachusetts Institute of Technology, an authority on hydrocarbons, on November 11, aged seventy-two years.

Prof. Edouard J. B. Goursat, formerly professor of mathematics in the Sorbonne, on November 26, aged seventy-eight years.

Dr. Henry B. Hedrick, formerly ballistician in the U.S. Ordnance Department, known for his work on the preparation of mathematical tables, on October 6, aged seventy-one years.

\title{
News and Views
}

\section{Louis-Bernard Guyton de Morveau (I737-1816)}

Ter bicentenary of the birth of Guyton de Morveau recalls the career of a man of science who was a prominent figure in what is, perhaps, the most interesting epoch in the history of science in France, if not in French history itself. Ingenious, versatile and courageous, he engaged in many enterprises and as a man of science had a wide reputation. Born at Dijon on January 4, 1737, Guyton de Morveau was the son of the professor of civil law in that city. $\mathrm{He}$ himself was educated for the law at Dijon and Paris, and after he had practised for a short time, his father procured for him at the price of 40,000 francs the appointment of advocate general to the local parliament at Dijon, which he held for twenty-three years. Always of an inquiring mind, he becarme attached to the Academy of Sciences in his native city, devoted himself to the study of chemistry--being assisted by Baumé-and in 1776 began to lecture on that subject. He also established on scientific principles a saltpetre factory which was conducted by Courtois, the father of the discoverer of iodine. He became acquainted with the men of science in Paris, and in 1780 he was induced by Panckoucke, the bookseller, to undertake the chemical section of the famous "Encyclopédie Methodique". Seven years later he joined Lavoisier, Berthollet and Fourcroy in the publication of the "Methode de Nomenclature Chimique", which revolutionized chemical nomenclature.

As with so many of his countrymen, at the outbreak of the Revolution, de Morveau's energies were diverted into another channel. He was chosen a deputy to the Legislative Assembly, of which he became secretary in 1791, and president the following year. In the Convention he was one of those who voted for the King's death; and in 1794 he accompanied the army into Belgium and made balloon ascents at the battle of Fleurus. With the return of more settled conditions he was made a professor in the newly founded Ecole Polytechnique, and in 1795 was chosen a member of the Council of Five Hundred, and also one of the forty-eight members of the National Institute which had arisen over the ashes of the old aeademies. He acted as director of the Ecole Polytechnique during the absence of Monge, who had accompanied Napoleon to Egypt, and he continued to lecture there until he was seventy-six years of age. He was made a baron in 1811, and died in Paris on January 2, 1816. The range of his writings can be seen from the list of more than 190 papers appended to the biographical sketch of him by Thomas Young in the earlier editions of the 
"Encyclopædia Britannica". He was one of the first to be converted to Lavoisier's views on combustion, and did much to make known the advances made by French chemists. No great discovery is associated with his name, but his influence on the progress of chemistry was far reaching.

\section{Mr. G. C. Robson}

ZooLogisTs, especially those interested in the study of Mollusca, will learn with regret that $\mathrm{Mr}$. G. C. Robson has been compelled by ill-health to resign from the scientific staff of the British Museum (Natural History). Mr. Robson went to the Museum from Oxford in 1911 as an assistant in the Department of Zoology, and devoted his attention to the Mollusca, studying more especially their anatomy and ecology. Among his more important works were his account of parthenogenesis in the gasteropod Paludestrina and his contributions to the systematics of the Cephalopoda, especially the Octopoda, on which he wrote a monograph published in two volumes by the Museum in 1929 and 1931. His interest in the more general aspects of biology is shown in his book "The Species Problem" (1928) and in the recent volume "The Variation of Animals in Nature" (1936), in which he collaborated with Dr. O. W. Richards. In 1931 he was appointed one of the two deputy keepers in the Department of Zoology. Mr. Robson's work at the Museum has brought him into contact with malacologists all over the world, and his many friends will hope that freedom from official responsibility will bring about his restoration to health and to scientific activity.

\section{Messel Research Fellowship}

Dr. J. E. Harris, of Christ's College, Cambridge, has been awarded a Messel research fellowship in biology by the Royal Society as from January 1. Dr. Harris held a Commonwealth Fund fellowship at Columbia University and the Guggenheim School of Aeronautics in 1933-35, and has since been University demonstrator in zoology at Cambridge. He proposes to investigate how far current morphological views on the evolution of the fins of fish are substantiated by a study of the functions of these organs. From an analysis of the effect of the fins on an accurate model of the dogfish suspended in a wind tunnel, it has been found possible to draw fairly definite conclusions concerning the action of these fins on the static stability of the living fish. It seems likely that an extension of these methods to other types will throw light on the relationship between the form of the fins and the habits and possible course of evolution of the different groups. The work will be combined with a study of the neuromuscular mechanism and of the forces produced by actively moving fins, the methods available for such study having already proved adequate. It is hoped that time will also permit of the confirmation and interpretation of Dr. Harris's somewhat striking observation, that there exists in the nucleus of the unfertilized egg of echinoderms a physical polarity which can be demonstrated by observations on the rate of free fall of the nucleolus in the germinal vesicle. Dr. Harris will work at Cambridge and possibly also at the Tortugas Laboratory of the Carnegie Institution of Washington, and the Guggenheim School of Aeronautics, New York.

\section{The British Broadcasting Corporation}

THE present British Broadcasting Corporation was granted its first charter of incorporation on December 20, 1926, and a supplemental charter on August 14, 1931. The special Committee, which was set up by the Postmaster-General, has recently conducted an inquiry into the broadcasting service and has recommended that the service should continue to be developed and exploited to the best advantage and in the national interest. This action is very desirable on account of the widespread interest in broadcasting, as illustrated by the fact that more than seven and a half million persons in Great Britain and Northern Ireland now have licences to instal apparatus for the reception of broadcast programmes. Accordingly, the British Broadcasting Corporation will continue in being under a new charter which came into operation on January 1, 1937, the draft of which has recently been published by H.M. Stationery Office as Cmd. 5329 (4d. net). In this paper, the objects of the Corporation are described in some detail; briefly, they may be summarized as the development, exploitation and maintenance of a public utility service for broadcasting to the public by means of wireless telephony and television any matter of interest, which may be permitted within the terms of the licence and agreement between H.M. Postmaster-General and the B.B.C. The draft of this licence is also included in the White Paper referred to above. The charter outlines the organization of the Corporation by means of a chairman, vicechairman and body of governors, and the chief executive officer of the Corporation is the directorgeneral. The Corporation is authorized and em. powered to receive and administer the funds granted annually by the legislative for the objects in view, and provision is made for the submission of an annual report and statement of accounts. To the lay mind, it is satisfactory to note from this paper that the broadcasting service in Great Britain will continue to maintain its unrivalled reputation, controlled and yet not hampered by Government administration, free to develop and exploit to the full the technique of broadcasting by both sound and vision.

\section{Salvador Earthquake of December 20}

For its size, the small republic of Salvador, containing only 7,225 square miles, has been visited by great destructive earthquakes more frequently than any other country. During the nineteenth century, there were at least fifteen such earthquakes, and Montessus records the ruin of San Salvador eleven times between 1538 and 1854. San Vicente, a town of 26,000 inhabitants and lying about 35 miles to the east of San Salvador, has suffered from earthquakes several times during the last century, and was almost ruined by a violent shock on the morning of December 20. With one 